\title{
Characteristics and Prognostic Factors of Recurrence after Hemithyroidectomy in Patients with Papillary Thyroid Microcarcinoma
}

\author{
Jihoon Lee, Gil Joon Lee, Jin Ho Sohn, and Dongbin Ahn (D) \\ Department of Otolaryngology-Head and Neck Surgery, School of Medicine, Kyungpook National University, Daegu, Korea
}

\section{갑상선 미세유두암 환자에서 반갑상선 절제술 후 재발의 특징 및 예후 인자}

이지훈 · 이길준 · 손진호 · 안동빈

경북대학교 의과대학 이비인후-두경부외과학교실

Received December 16, 2019

Revised February 20, 2020

Accepted February 24, 2020

Address for correspondence

Dongbin Ahn, MD

Department of Otolaryngology-

Head and Neck Surgery,

School of Medicine,

Kyungpook National University,

130 Dongdeok-ro, Jung-gu,

Daegu 41944, Korea

Tel $+82-53-200-5781$

Fax $+82-53-200-4524$

E-mail godlikeu@naver.com
Background and Objectives The incidence of papillary thyroid microcarcinoma (PTMC) continues to increase worldwide. However, there is a lack of a comprehensive understanding of recurrence after hemithyroidectomy in patients with PTMC. We aimed to evaluate the characteristics and risk factors of recurrence after hemithyroidectomy in patients with PTMC.

Subjects and Method We included 527 patients with PTMC who underwent hemithyroidectomy between 2009 and 2017.

Results At a mean follow-up of 76.4 months after hemithyroidectomy, recurrence occurred in $4.2 \%(22 / 527)$ of the patients. The times of recurrence were $<12,12-24,24-36,36-48,48-$ 60 , and $>60$ months after initial surgery in 1 (4.5\%), 6 (27.3\%), 5 (22.7\%), 4 (18.2\%), 4 (18.2\%), and $2(9.1 \%)$ patient(s), respectively. The most common recurrence site was the contralateral remaining thyroid lobe. In univariate analyses, only multifocality was demonstrated to be associated with an increased risk of recurrence [hazard ratio (HR), 2.834; confidence interval (CI), 1.044-7.693; $p=0.041)$. In multivariate analyses, multifocality (HR, 2.982; CI, 1.091$8.155 ; p=0.033$ ) and central lymph node metastasis (HR, 9.649; CI, 1.238-75.217; $p=0.030$ ) were demonstrated to be associated with an increased risk of recurrence.

Conclusion The follow-up after hemithyroidectomy for PTMC should focus on the postoperative 1-5-year period with meticulous inspection of the remaining thyroid lobe, particularly in patients with multifocality or central lymph node metastasis.

Korean J Otorhinolaryngol-Head Neck Surg 2021;64(1):19-25

Key Words Papillary thyroid cacer $\cdot$ Prognosis $\cdot$ Recurrence $\cdot$ Risk factors ·

Thyroidectomy.
서 론

갑상선 유두암은 갑상선에서 가장 흔한 악성 종양이며, 전 세계적으로 그 발생율이 지속적으로 증가하고 있다. ${ }^{1-3)}$ 미국 National Cancer Institute에서 1975 2016년까지 조사된 Sur-

This is an Open Access article distributed under the terms of the Creative Commons Attribution Non-Commercial License (https://creativecommons.org/licenses/by-nc/4.0) which permits unrestricted non-commercial use, distribution, and reproduction in any medium, provided the original work is properly cited. veillance, Epidemiology, and End Result(SEER) 자료에 따 르면, 갑상선암의 연령표준화 발생률은 인구 10만 명당 1975 년에 4.93명에서 2016년에 14.6명으로 약 3배가량 증가한 것 으로 나타났다. ${ }^{4)}$ 국립암센터에서 조사한 국내 데이터에서도 1999년에 인구 10만 명당 7.0명을 기록한 갑상선암 연령표준 화 발생률은 지속적으로 증가하여 2012년에 10만 명당 72명 으로 최대치를 기록한 이후 다소 감소 추세를 보였지만, 2016 년에도 인구 10 만 명당 44.1 명의 발생율로 여전히 매우 높은 
수치를 보이고 있다. ${ }^{5)}$

이러한 갑상선암 발생률 증가의 상당 부분은 무증상 환자 들에서 검진으로 발견된 직경 $1 \mathrm{~cm}$ 미만의 갑상선 미세유두 암의 증가로 인한 것으로 생각되며, 실제 2014년 World Health Organization에서 보고한 World Cancer Report에 따르면 전세계에서 새롭게 진단되는 갑상선암의 $50 \%$ 이상이 갑상선 미세유두암인 것으로 나타났다. ${ }^{3,6,7)}$

하지만 갑상선 미세유두암의 치료에 대해서는 아직까지 하 나의 정립된 방침이 없어서, 갑상선 미세유두암이 흔히 다발 성으로 존재한다는 사실과 수술 후 추적 관찰의 용이성 등 을 근거로 갑상선 전절제술을 시행하는 경우부터, 유두암의 매우 느린 진행 경과를 바탕으로 수술 없이 정기적인 경과 관 찰 만을 시행하는 적극적 감시(active surveillance) 방법까지 매우 다양한 치료방침이 적용되고 있는 실정이다. ${ }^{8-12)}$

2009년에 처음 발표되어 2015년에 개정된 미국갑상선학회 갑상선암 진료 지침 및 이를 바탕으로 한 대한갑상선학회 권 고안에서는 크기가 $1 \mathrm{~cm}$ 미만이면서 갑상선 외 침윤이 없으 며, 임상적으로 경부림프절 전이의 증거가 없고 경부방사선 조사력이나 가족력이 없는 갑상선암의 경우 갑상선 엽절제 술을 권고하고 있다. ${ }^{13,14)}$ 하지만 지난 수십 년 동안 실제 임상 에서 갑상선 미세유두암에 적용된 수술 범위에 대한 연구를 살펴보면, 1936 2015년까지 Mayo Clinic에서 갑상선 미세 유두암으로 수술 받은 1376 명의 환자들 중 $15 \%$ 만이 갑상선 엽절제술을 받았으며, 2008 2016년까지 위스콘신대학병원 에서 갑상선 미세유두암으로 수술 받은 125명중 34명(27.2\%) 만 엽절제술이 시행되었다. ${ }^{15,16)}$ 또한 1998 2010년 사이의 SEER 자료에 따르면 갑상선 미세유두암 환자들의 $25.2 \%$ 만이 갑상선 부분절제술을 시행 받아, 갑상선 미세유두암 환자에 서 갑상선 엽절제술이 적용된 비율은 생각보다 높지 않으며, 그에 따라 갑상선 미세유두암 환자에서 갑상선 엽절제술 후 발생하는 재발에 대한 연구는 아직 많이 부족한 실정이다. ${ }^{17)}$ 또한 현재까지 나이, 성별, 종양의 크기, 종양의 다발성, 피막 외 침범, 하시모토 갑상선염의 동반, 중심경부림프절 절제술 여부, 림프절 전이 여부 등 매우 다양한 예후 인자들이 보고 되고 있으나, 대부분의 연구에서 다양한 병기와 수술 범위를 가진 환자들을 한꺼번에 포함하여 분석을 진행하였기 때문 에, 반갑상선 절제술을 받은 갑상선 미세유두암 환자들에게 이러한 결과들을 일괄적으로 적용하기에는 무리가 있다..$^{18-21)}$ 이에 본 저자들은 이번 연구를 통해 갑상선 미세유두암 환 자에서 반갑상선 절제술 후 발생하는 재발의 빈도와 양상, 그리고 관련 위험인자들에 대해 분석해보고자 하였다.

\section{대상 및 방법}

2009년 1월 2017년 6월까지 본 기관에서 저자들에게 반갑 상선 절제술을 시행 받은 655 명의 환자 중, 방사선 조사나 다 른 두경부암의 과거력이 있는 경우 $(\mathrm{n}=6)$, 술후 시행된 병리조 직학적 진단에서 양성 혹은 갑상선 유두암의 변이종으로 확 인된 경우 $(\mathrm{n}=52)$, 갑상선 유두암의 크기가 $1 \mathrm{~cm}$ 보다 큰 경우 $(\mathrm{n}=45)$, 그리고 추적 관찰 기간이 24 개월 미만인 경우 $(\mathrm{n}=25)$ 등의 128 명을 제외한 527 명이 본 연구에 최종 포함되었다. 해당 연구 기간 동안의 반갑상선 절제술은 2009년 미국갑상 선학회 진료 지침에 따라 이루어졌으며, 중심경부림프절 절 제술 역시 동일한 진료 지침을 참고하여 본 연구 대상이 되는 반갑상선 절제술의 적응이 되는 갑상선 미세유두암 환자에 있어서 중심경부림프절 절제술이 일괄적으로 시행되지는 않 았다. 다만 반갑상선 절제술 중 육안 또는 촉진상 비대된 중 심경부림프절이 확인된 경우 해당 림프절을 제거하기 위한 목적으로 중심경부림프절 절제술이 시행되었다. ${ }^{22)}$

본 연구에 포함된 모든 환자들은 수술 후 첫 번째로는 1 개 월 후, 두 번째로는 3개월, 그 이후는 매 6개월 간격으로 추적 관찰을 시행 받았으며, 재발 여부는 신체 검진을 비롯한 영 상학적 검사를 통하여 확인하였다. 정기적인 영상검사로는 경부 초음파를 시행하였으며, 수술 후 3개월 째 처음으로 실 시한 이후로 매 6 개월마다 반복하였다. 경부 초음파 검사에서 재발이 의심되는 병변이 있는 경우는 초음파 유도하 세침흡 인검사 또는 중심바늘생검을 시행하였고, 이를 통해 구조적 재발이 확인된 경우 수술의 금기가 없는 모든 환자에서 수술 을 통해 해당 병변을 제거하였다. 경부 초음파 검사에서는 재 발이 의심되는 병변이 확인되었으나, 경동정맥이나 쇄골하 동 정맥 등의 대혈관 후방에 위치하여 세침흡인검사 또는 중심 바늘생검을 실시하기가 어려운 경우, 그리고 초음파 소견과 세침흡인검사 또는 중심바늘생검 등을 통해 얻어진 병리 소 견상의 불일치가 있는 경우에는 경부 전산화단층촬영이나 양전자방출 전산화단층촬영을 추가로 시행하여 재발 여부를 확인하고자 하였다. 경과 관찰 중 갑상선암의 재발을 막기 위 한 목적의 일괄적인 갑상선 자극호르몬 억제치료는 시행하지 않았다.

대상 환자들의 나이, 성별, 종양의 크기, 갑상선 피막 외 침 범 여부, 다발성 여부, 림프혈관계침범 여부, 절제연의 침범 여 부, 하시모토 갑상선염의 동반 유무, 중심경부림프절의 전이 여부, 재발 시기 및 위치 등을 확인하였으며, 이러한 항목들 을 수술 후 재발 여부에 따라 비교분석 하였다. 재발 위치는 본 기관에서 재발에 대한 수술을 받은 경우 수술 후 확인된 최종 병리소견을 근거로 하였으며, 본 기관에서 재발 확인 후 
타 기관으로 전원 되어 수술 받은 환자의 경우 본 기관에서 재발이 확인된 영상 검사와 술전 병리 검사를 근거로 재발 위치를 기술하였다.

모든 통계분석은 SPSS(version 18; SPSS Inc., Chicago, IL, USA)를 사용하였으며, 범주형 변수에 대해서는 chi-square test 혹은 Fisher's exact test를, 연속형 변수에 대해서는 independent student's t-test를 이용하여 분석하였다. 재발의 위험 요인 분석을 위해서는 Cox-regression 모델을 통해 단 변량 및 다변량 분석을 하였다. 다변량 분석은 단변량 분석 에서 얻어진 유의 수준이 0.3 보다 작은 변수들을 포함하여 시행하였다.

본 연구는 자료분석을 통한 후향적 연구로서 소속 기관의 임 상시험심사위원회의 심의를 면제받았다(IRB No. 201910002).

\section{결 과}

전체 527 명 대상 환자들의 임상병리적 소견은 Table 1 에 나 타내었다. 평균 나이는 46.9세(18 77세)였으며, 55세 미만이 394 명(74.8\%), 55세 이상이 133명(25.2\%)이었다. 성별은 여성 이 446명(84.6\%), 남성 81명(15.4\%)이었다. 원발암의 크기는 $0.5 \mathrm{~cm}$ 이하가 269명(51.0\%), 0.5 1 cm 사이가 258명(49.0\%) 이었다. 현미경적 갑상선 피막 외 침범이 확인된 경우는 114 명으로 전체의 $21.6 \%$ 를 차지하였다. 다발성을 보이는 경우는 54 명(10.2\%)에서 관찰되었으며, 림프혈관계침범을 보이는 경 우는 없었다. 절제연은 모든 환자에서 음성이었다. 하시모토 갑상선염이 동반된 경우는 121 명(23.0\%)이었으며, 중심경부 림프절 절제술을 시행한 51 명 중 전이가 확인된 경우는 6명 (11.8\%)이었다.

평균 76.4 개월간 추적 관찰 동안 총 22 명에서 재발이 확인 되어 전체 재발률은 $4.2 \%$ 였다. 재발한 환자들의 평균 재발 시기는 수술 후 39 개월째였다. 재발의 기간에 대해 좀 더 살 펴보면, 술후 12 개월 이내에 재발한 경우는 1 명(4.5\%)에 불과 하였으며, 술후 12 24개월의 기간에서의 재발이 6명(27.3\%), 24 36개월의 기간에서 5명(22.7\%), 36 48개월의 기간에서 4명(18.2\%), 48 60개월의 기간에서 4명(18.2\%)이었으며 60개 월 이후의 재발은 2 명(9.1\%)에서만 확인되었다(Fig. 1).

재발군 22 명의 재발 위치를 살펴보면, 반대측 잔존 갑상선 엽에서의 재발이 15 명(68.2\%)으로 가장 많았으며, 반대측 갑 상선엽과 동측의 중심경부림프절에서 재발한 경우가 2명 (9.1\%), 반대측 갑상선엽과 동측의 중심경부 및 측경부림프절 에서 재발한 경우 3 명(13.6\%), 그리고 동측 중심경부림프절에 서만 재발한 경우는 2 명(9.1\%)에서 확인되었다.

재발군과 비재발군에 대한 임상병리학적 특징은 Table 2에
Table 1. Baseline patients characteristics

\begin{tabular}{|c|c|}
\hline Variables & $\begin{array}{l}\text { Number of patients (\%) } \\
\qquad(n=527)\end{array}$ \\
\hline \multicolumn{2}{|l|}{ Age (years) } \\
\hline Mean & $46.9(18-77)$ \\
\hline$<55$ & $394(74.8)$ \\
\hline$\geq 55$ & $133(25.2)$ \\
\hline \multicolumn{2}{|l|}{ Sex } \\
\hline Male & $81(15.4)$ \\
\hline Female & $446(84.6)$ \\
\hline Follow-up period (months) & $76.4(24-124)$ \\
\hline \multicolumn{2}{|l|}{ Tumor size $(\mathrm{cm})$} \\
\hline Mean & $0.6(0.1-1.0)$ \\
\hline$\leq 0.5$ & $269(51.0)$ \\
\hline $0.5-1.0$ & $258(49.0)$ \\
\hline \multicolumn{2}{|l|}{ Microscopic ETE } \\
\hline No & $413(78.4)$ \\
\hline Yes & $114(21.6)$ \\
\hline \multicolumn{2}{|l|}{ Multifocality } \\
\hline No & $473(89.8)$ \\
\hline Yes & $54(10.2)$ \\
\hline \multicolumn{2}{|l|}{ Lymphovascular invasion } \\
\hline No & $527(100.0)$ \\
\hline Yes & $0(0.0)$ \\
\hline \multicolumn{2}{|l|}{ Margin } \\
\hline No & $527(100.0)$ \\
\hline Yes & $0(0.0)$ \\
\hline \multicolumn{2}{|l|}{ Concurrent HT } \\
\hline No & $406(77.0)$ \\
\hline Yes & $121(23.0)$ \\
\hline \multicolumn{2}{|c|}{ Central neck metastasis $(n=51)^{*}$} \\
\hline No & $45(88.2)$ \\
\hline Yes & $6(11.8)$ \\
\hline
\end{tabular}

* central neck dissection was performed only in 51 patients. ETE: extrathyroidal extension, HT: Hashimoto's thyroiditis

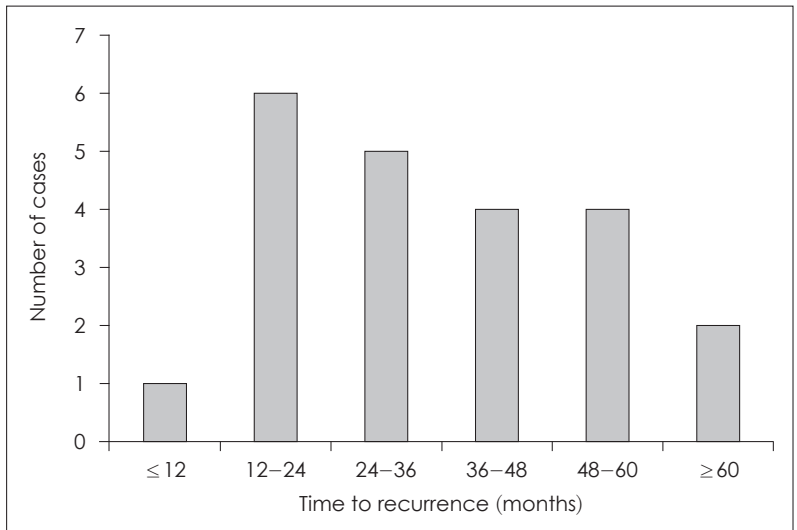

Fig. 1. Distribution of time to recurrence after hemithryoidectomy in patients with papillary thyroid microcarcinoma. 
비교하였다. 환자의 나이, 성별, 종양의 크기, 현미경적 갑상선 피막 외 침범, 림프혈관계침범 여부, 절제연의 침범 여부, 하 시모토 갑상선염의 동반 여부 그리고 중심경부림프절의 전이

Table 2. Association between clinicopathological characteristics and recurrence

\begin{tabular}{|c|c|c|c|}
\hline Variables & $\begin{array}{c}\text { Recurrence }(-) \\
(n=505)(\%)\end{array}$ & $\begin{array}{c}\text { Recurrence }(+) \\
(n=22)(\%)\end{array}$ & p-value \\
\hline \multicolumn{3}{|l|}{ Age (years) } & 0.436 \\
\hline Mean & $47.0(18-77)$ & $46.8(34-61)$ & \\
\hline$<55$ & $376(74.5)$ & $18(81.8)$ & \\
\hline$\geq 55$ & $129(25.5)$ & $4(18.2)$ & \\
\hline \multicolumn{3}{|l|}{ Sex } & 0.227 \\
\hline Male & $81(16.0)$ & $1(4.5)$ & \\
\hline Female & $424(84.0)$ & $21(95.5)$ & \\
\hline \multicolumn{3}{|l|}{ Tumor size (cm) } & 0.227 \\
\hline Mean & $0.6(0.1-1.0)$ & $0.5(0.2-0.9)$ & \\
\hline$\leq 0.5$ & $255(50.5)$ & $14(63.6)$ & \\
\hline $0.5-1.0$ & $250(49.5)$ & $8(36.4)$ & \\
\hline \multicolumn{3}{|l|}{ Microscopic ETE } & 0.596 \\
\hline No & $397(78.6)$ & $16(72.7)$ & \\
\hline Yes & $108(21.4)$ & $6(27.3)$ & \\
\hline \multicolumn{3}{|l|}{ Multifocality } & 0.064 \\
\hline No & $456(90.3)$ & $17(77.3)$ & \\
\hline Yes & $49(9.7)$ & $5(22.7)$ & \\
\hline \multicolumn{3}{|c|}{ Lymphovascular invasion } & $>0.999$ \\
\hline No & $505(100.0)$ & $22(100.0)$ & \\
\hline Yes & $0(0.0)$ & $0(0.0)$ & \\
\hline \multicolumn{3}{|l|}{ Surgical margin } & $>0.999$ \\
\hline No & $505(100.0)$ & $22(100.0)$ & \\
\hline Yes & $0(0.0)$ & $0(0.0)$ & \\
\hline \multicolumn{3}{|l|}{ Concurrent HT } & 0.313 \\
\hline No & $391(77.4)$ & $15(68.2)$ & \\
\hline Yes & $114(22.6)$ & $7(31.8)$ & \\
\hline \multicolumn{3}{|c|}{ Central neck metastasis* } & 0.227 \\
\hline No or unexplored & $500(99.0)$ & $21(95.5)$ & \\
\hline Yes & $5(1.0)$ & $1(4.5)$ & \\
\hline
\end{tabular}

여부에서 두 군 간의 유의한 차이는 없었다. 다발성의 경우 재발군의 $22.7 \%$ 에서 관찰된 반면, 비재발군에서는 $9.7 \%$ 에서 만 관찰되어 그 차이가 가장 뚜렷하였으나, 통계적 유의성은 나타내지 못하였다 $(p=0.064)$.

재발의 위험인자 확인을 위한 단변량 분석에서는 나이 $(\geq$ 55 세), 여성, 종양 크기 $(>0.5 \mathrm{~cm})$, 피막 외 침범, 다발성, 하시 모토 갑상선염의 동반, 중심림프절 전이 등의 항목 중 다발성 항목만이 통계학적으로 유의하게 재발과의 상관관계를 보였 으며(위험비, 2.834; 신뢰구간 1.044 7.693; $p=0.041$ ), 중심경 부림프절의 전이의 경우 위험비가 7.253으로 매우 높았으나, 경계 유의성을 보였다 $(p=0.055)$. 다변량 분석에서 다발성 항 목은 여전히 통계적으로 유의하게 재발과 상관관계가 있는 것으로 나타났으며(위험비, 2.982; 신뢰구간 1.091 8.155; $p=$ 0.033), 중심경부림프절 전이 역시 통계적으로 유의하게 재발 과 상관관계가 있는 것으로 확인되었다(위험비, 9.649; 신뢰 구간 1.238 75.217; $p=0.030$ )(Table 3).

\section{고 찰}

갑상선 미세유두암은 임상적으로 증상을 보이지 않고 진행 양상이 매우 느리기 때문에 과거에는 비갑상선 질환으로 사 망한 환자의 부검 소견이나 양성 갑상선 질환으로 수술을 받 은 환자의 검체에서 우연히 발견되는 경우가 많았다. ${ }^{23)}$ 그러나 최근 들어서는 갑상선 초음파의 발달과 세침흡인검사 등을 이용한 조기진단의 확대로 유병률이 지속적으로 높아지고 있고, 전반적으로 좋은 예후에도 불구하여 일부 환자들에서 는 수술 후 재발, 림프절 전이 및 원격 전이, 그리고 사망에 이르는 결과까지 보고되고 있기 때문에 갑상선 미세유두암 에 대한 임상적인 중요성이 강조되고 있다. ${ }^{24-26)}$

본 연구에서 갑상선 미세유두암에 대한 엽절제술 후 재발 하기까지의 평균 기간은 39 개월로, 최근의 다른 연구에서의 4.4년과 크게 다르지 않았으며, 술후 1 3년 사이의 재발이 전 체 재발의 50\%(11/22)를 차지했고, 1 5년 사이의 재발이 전

Table 3. Univariate and multivariate analyses for risk of recurrence

\begin{tabular}{|c|c|c|c|c|c|c|}
\hline \multirow{2}{*}{ Variables } & \multicolumn{3}{|c|}{ Univariate } & \multicolumn{3}{|c|}{ Multivariate } \\
\hline & $\mathrm{HR}$ & $\mathrm{Cl}$ & $p$-value & $\mathrm{HR}$ & $\mathrm{Cl}$ & $p$-value \\
\hline Age $\geq 55$-year-old & 0.660 & $0.223-1.952$ & 0.453 & - & - & - \\
\hline Female sex & 3.601 & $0.484-26.809$ & 0.211 & 3.794 & $0.508-28.302$ & 0.193 \\
\hline Tumor size $>0.5 \mathrm{~cm}$ & 0.578 & $0.242-1.377$ & 0.216 & 0.581 & $0.243-1.388$ & 0.222 \\
\hline Microscopic ETE & 1.287 & $0.503-3.289$ & 0.599 & - & - & - \\
\hline Multifocality & 2.834 & $1.044-7.693$ & 0.041 & 2.982 & $1.091-8.155$ & 0.033 \\
\hline Concurrent HT & 1.584 & $0.646-3.885$ & 0.315 & - & - & - \\
\hline Central neck metastasis & 7.253 & $0.956-55.006$ & 0.055 & 9.649 & $1.238-75.217$ & 0.030 \\
\hline
\end{tabular}

HR: hazard ratio, Cl: confidence interval, ETE: extrathyroidal extension, HT: Hashimoto's thyroiditis 
체의 86.3\%(19/22)를 차지하여, 대부분의 재발이 1 5년 사이 에 발생함을 알 수 있었다. ${ }^{27)}$ 이러한 결과를 바탕으로 술후 환자를 추적 관찰함에 있어 술후 1년 이내 및 5년 이후에는 재발 평가를 위한 정기적인 영상검사를 최소화 할 수 있을 것 으로 생각된다. 실제로 대한갑상선학회 권고안에 따르면 수술 후 6 12개월에 첫 초음파 검사를 시행하고 그 이후로 재발 위험도에 따라 주기적인 검사를 하도록 하고 있으며, 수술 후 5 년이 지난 경우에는 매년 초음파를 시행할 필요는 없다는 보고들도 있다. ${ }^{14,28,29)}$ 다만 갑상선암은 수술 후 20년 이상이 지나서도 재발하는 경우가 보고되기도 하므로 환자에게 술후 5 년이 지났더라도 재발의 가능성이 있음을 설명하고, 경부 종물 등의 재발 징후가 나타나면 적절한 검사를 받을 수 있 도록 충분히 교육하여야 할 것으로 생각된다. ${ }^{30}$

이번 연구 결과 갑상선 반절제술 후 발생한 재발의 위치로 는 반대측 잔존 갑상선 단독인 경우가 $68.2 \%$ 로 가장 흔했는 데, 이는 최근 보고된 문헌들의 수치(58.0 84.6\%)와도 유사한 결과였다. ${ }^{27,31)}$ 특히, 본 연구에서는 반대측 잔존 갑상선엽에서 의 재발 및 경부림프절 전이가 동반된 경우까지 포함시킬 경 우, 전체 재발의 $90.9 \%$ 가 잔존 갑상선엽을 포함하고 있었다. 따라서 갑상선 미세유두암으로 갑상선 반절제술 시행 후 추 적 관찰을 할 때에는 기존 갑상선 수술 자리나 림프절보다는 남아있는 반대측 갑상선에 대한 면밀한 검사가 반드시 필요 할 것으로 생각된다. 다만, 전체 22 명의 재발군 중에서 반대측 잔존 갑상선엽에서 재발이 확인된 2명과 반대측 갑상선엽 및 동측의 중심경부림프절 모두에서 재발이 확인된 1 명, 총 3 명 의 재발 위치는 재수술이 타 기관에서 이루어져 최종병리조 직검사를 확인할 수 없었던 경우로, 재수술 전 시행한 세침흡 인검사 및 중심바늘생검 결과를 바탕으로 재발의 위치를 기 술하였다. 이 때문에 재발 위치에 대한 통계분석 시에 반대측 잔존 갑상선 단독에서 재발한 경우의 비율이 실제보다 부풀 려졌을 가능성과 측경부림프절에서 재발한 비율이 실제보다 축소되었을 가능성이 있다. 그러나 전체 재발의 $90 \%$ 이상이 잔존 갑상선엽을 포함하고 있다는 결과에는 변화가 없다.

본 연구에서는 갑상선 유두암의 예후 인자로 알려진 다양 한 변수들에 대해 재발 여부에 따른 차이를 비교 분석하였으 나, 어떠한 변수들에서도 재발과 비재발군 사이의 유의미한 차이를 발견할 수는 없었다. 다만 Cox 회귀분석을 통한 단변 량, 다변량 분석에서는 다발성 미세 유두암일 경우 재발과 통 계적으로 유의미한 관계가 있음을 확인할 수 있었는데, 이는 갑상선 미세유두암종에서 다발성 여부에 따른 예후를 분석한 저자들의 이전 연구에 비해 다소 발전된 것이라 할 수 있다. ${ }^{32)}$ 당시 연구에서는 다발성과 단발성의 미세유두암종을 가진 환자의 엽절제술 후 재발률이 각각 $10.3 \%$ 와 $4.4 \%$ 로 상당한
차이를 보였음에도 불구하고 통계학적 유의성을 증명하는 데 에는 실패하였으며, 단변량, 다변량 분석에서도 다발성 여부 와 재발과의 상관 관계를 증명하지 못하였다. 하지만 이전 연 구에 비해 대상 환자 수 및 추적 관찰 기간이 늘어난 이번 연 구에서는 다발성 여부가 수술 후 재발과 통계적으로 유의미 한 관계가 있음을 확인할 수 있었다. 최근 발표된 1249명의 갑 상선 유두암 환자들을 대상으로 한 연구에서도 다발성을 보 이는 갑상선 유두암 환자들은 단발성인 경우보다 수술 후 재 발율이 높았으며, 또한 대상을 갑상선 미세유두암으로 한정 하여 15 년간의 데이터를 후향적으로 분석한 다른 연구에서 도 다발성 여부가 재발에 대한 독립적인 위험인자임을 보고 하여 이번 저자들의 연구 결과와 일치하였다. ${ }^{33,34)}$

본 연구에서는 다발성 외에 중심경부림프절의 전이 역시 재 발과 유의한 상관관계를 보였는데, 이러한 결과를 평가함에 있어서는 본 연구에 포함된 환자들의 매우 일부에서만 중심 림프절 절제술이 이루어졌다는 사실을 우선 고려해야 할 것 으로 생각된다. 즉 전체 포함 환자의 약 9.7\%(51/527)에서만 중심림프절 절제술이 시행되었고, 이들 중 $11.8 \%(6 / 51)$ 에서만 중심림프절 전이가 확인되었기 때문에, 중심림프절 절제술을 시행하게 된 선택 편견 및 해당 변수의 적은 환자 수 등을 고 려할 때, 이번 연구 결과만을 근거로 중심림프절 전이가 반갑 상선 절제술을 시행 받은 갑상선 미세유두암 환자에서 재발 의 위험인자로 작용한다는 결론을 내리기에는 무리가 있을 것으로 생각되는 바이다. 다만 재발을 보인 22 명의 재발 양 상을 분석해 보았을 때 약 $1 / 3(31.8 \%, 7 / 22)$ 의 환자에서 동측 중심림프절에서의 재발을 보였다는 점을 고려하면, 반갑상선 절제술의 대상이 되는 갑상선 미세유두암 환자에서 동측의 중심림프절 절제술을 시행할 경우 이러한 동측 중심림프절 에서의 재발을 예방하는 데 도움이 될 수 있을 것이라 추정 해 볼 수 있다.

요약하면 본 기관에서 갑상선 미세유두암에 대한 반갑상 선절제술 후의 재발율은 $4.2 \%$ 였으며, 재발의 위치는 잔존갑 상선인 경우가 가장 많았다. 대부분의 재발 시점은 수술 후 1 5년 사이였으며, 다발성과 중심경부림프절 전이가 재발의 독립적인 위험인자로 나타났다. 따라서 반갑상선 절제술을 시행 받은 갑상선 미세유두암 환자의 추적 관찰에 있어, 술후 1 5년 사이의 기간 동안에 잔존 갑상선엽에 대한 집중 관찰 이 필요할 것으로 생각되며, 특히 병리조직검사에서 다발성 이나 중심경부림프절의 전이가 확인된 경우 보다 주의 깊은 관찰이 필요할 것으로 생각되는 바이다.

\section{Acknowledgments}

None. 


\section{Author Contribution}

Conceptualization: Dongbin Ahn. Data curation: Dongbin Ahn, Jihoon Lee. Investigation: Dongbin Ahn, Gil Joon Lee, Jin Ho Sohn. Methodology: Dongbin Ahn, Gil Joon Lee, Jin Ho Sohn. Supervision: Dongbin Ahn, Gil Joon Lee, Jin Ho Sohn. Validation: Dongbin Ahn. Writing - original draft: Jihoon Lee. Writing - review \& editing: Dongbin Ahn, Jihoon Lee.

\section{ORCID}

Dongbin Ahn https://orcid.org/0000-0002-4977-7406

\section{REFERENCES}

1) Davies L, Welch HG. Current thyroid cancer trends in the United States. JAMA Otolaryngol Head Neck Surg 2014;140(4):317-22.

2) Ahn HS, Welch HG. South Korea's thyroid-cancer "Epidemic"-turning the tide. N Engl J Med 2015;373(24):2389-90.

3) Davies L, Morris LG, Haymart M, Chen AY, Goldenberg D, Morris $\mathrm{J}$, et al. American Association of Clinical Endocrinologists and American College of Endocrinology disease state clinical review: The increasing incidence of thyroid cancer. Endocr Pract 2015; 21(6):686-96

4) Noone AM, Howlader N, Krapcho M, Miller D, Brest A, Yu M, et al. SEER Cancer Statistics Review (CSR) 1975-2015 [cited 2020 Jul 7]. Available from: URL: https://seer.cancer.gov/archive/ csr/1975 2015

5) Jung KW, Won YJ, Kong HJ, Lee ES. Cancer statistics in Korea: Incidence, mortality, survival, and prevalence in 2016. Cancer Res Treat 2019;51(2):417-30.

6) Boon TW, Parameswaran R. Epidemiology of thyroid cancer. In: Parameswaran R, Agarwal A, editor. Evidence-Based Endocrine Surgery. Berlin: Springer;2018. p.33-9.

7) McGuire S. World cancer report 2014. Geneva, Switzerland: World Health Organization, International Agency for Research on Cancer, WHO Press, 2015. Adv Nutr 2016;7(2):418-9.

8) Merdad M, Eskander A, De Almeida J, Freeman J, Rotstein L, Ezzat $\mathrm{S}$, et al. Current management of papillary thyroid microcarcinoma in Canada. J Otolaryngol Head Neck Surg 2014;43(1):32.

9) Wu AW, Nguyen C, Wang MB. What is the best treatment for papillary thyroid microcarcinoma? Laryngoscope 2011;121(9): 1828-9.

10) Ito $Y$, Miyauchi A, Oda H. Low-risk papillary microcarcinoma of the thyroid: A review of active surveillance trials. Eur J Surg Oncol 2018;44(3):307-15.

11) Leboulleux S, Tuttle RM, Pacini F, Schlumberger M. Papillary thyroid microcarcinoma: Time to shift from surgery to active surveillance? Lancet Diabetes Endocrinol 2016;4(11):933-42.

12) Miyauchi A. Clinical trials of active surveillance of papillary microcarcinoma of the thyroid. World J Surg 2016;40(3):516-22.

13) Haugen BR, Alexander EK, Bible KC, Doherty GM, Mandel SJ, Nikiforov YE, et al. 2015 American Thyroid Association management guidelines for adult patients with thyroid nodules and differentiated thyroid cancer: The American Thyroid Association guidelines task force on thyroid nodules and differentiated thyroid cancer. Thyroid 2016;26(1):1-133.

14) Yi KH, Lee EK, Kang HC, Koh Y, Kim SW, Kim IJ, et al. 2016 revised Korean Thyroid Association management guidelines for patients with thyroid nodules and thyroid cancer. Int J Thyroidol 2016;9(2):59-126.

15) Hay ID, Johnson TR, Kaggal S, Reinalda MS, Iniguez-Ariza NM, Grant CS, et al. Papillary thyroid carcinoma (PTC) in children and adults: Comparison of initial presentation and long-term postoperative outcome in 4432 patients consecutively treated at the Mayo Clinic during eight decades (1936-2015). World J Surg 2018;42(2):329-42.
16) Price AK, Randle RW, Schneider DF, Sippel RS, Pitt SC. Papillary thyroid microcarcinoma: Decision-making, extent of surgery, and outcomes. J Surg Res 2017;218:237-45.

17) Wang TS, Goffredo P, Sosa JA, Roman SA. Papillary thyroid microcarcinoma: An over-treated malignancy? World J Surg 2014;38(9):2297-303.

18) Hyun SM, Song HY, Kim SY, Nam SY, Roh JL, Han MW, et al. Impact of combined prophylactic unilateral central neck dissection and hemithyroidectomy in patients with papillary thyroid microcarcinoma. Ann Surg Oncol 2012;19(2):591-6.

19) Lee CR, Son H, Lee S, Kang SW, Jeong JJ, Nam KH, et al. Lobectomy and prophylactic central neck dissection for papillary thyroid microcarcinoma: Do involved lymph nodes mandate completion thyroidectomy? World J Surg 2014;38(4):872-7.

20) Siddiqui S, White MG, Antic T, Grogan RH, Angelos P, Kaplan EL, et al. Clinical and pathologic predictors of lymph node metastasis and recurrence in papillary thyroid microcarcinoma. Thyroid 2016;26(6):807-15.

21) Son HJ, Kim JK, Jung YD, Jang GH, Seo YT, Kim DS, et al. Comparison of outcomes between hemithyroidectomy alone and hemithyroidectomy with elective unilateral central neck dissection in patients with papillary thyroid microcarcinoma. Head Neck 2018;40(11):2449-54.

22) American Thyroid Association (ATA) Guidelines Taskforce on Thyroid Nodules and Differentiated Thyroid Cancer; Cooper DS, Doherty GM, Haugen BR, Kloos RT, Lee SL, et al. Revised American Thyroid Association management guidelines for patients with thyroid nodules and differentiated thyroid cancer. Thyroid 2009;19(11):1167-214.

23) Sampson RJ, Key CR, Buncher CR, Iijima S. Thyroid carcinoma in Hiroshima and Nagasaki. I. Prevalence of thyroid carcinoma at autopsy. JAMA 1969;209(1):65-70.

24) Cappelli C, Castellano M, Braga M, Gandossi E, Pirola I, De Martino E, et al. Aggressiveness and outcome of papillary thyroid carcinoma (PTC) versus microcarcinoma (PMC): A monoinstitutional experience. J Surg Oncol 2007;95(7):555-60.

25) Pearce EN, Braverman LE. Papillary thyroid microcarcinoma outcomes and implications for treatment. J Clin Endocrinol Metab 2004;89(8):3710-2

26) Chow SM, Law SC, Chan JK, Au SK, Yau S, Lau WH. Papillary microcarcinoma of the thyroid-prognostic significance of lymph node metastasis and multifocality. Cancer 2003;98(1):31-40.

27) Kwon H, Jeon MJ, Kim WG, Park S, Kim M, Song DE, et al. A comparison of lobectomy and total thyroidectomy in patients with papillary thyroid microcarcinoma: A retrospective individual risk factor-matched cohort study. Eur J Endocrinol 2017;176(4):371-8.

28) Cailleux AF, Baudin E, Travagli JP, Ricard M, Schlumberger M. Is diagnostic iodine-131 scanning useful after total thyroid ablation for differentiated thyroid cancer? J Clin Endocrinol Metab 2000; 85(1):175-8.

29) Durante C, Attard M, Torlontano M, Ronga G, Monzani F, Costante $\mathrm{G}$, et al. Identification and optimal postsurgical follow-up of patients with very low-risk papillary thyroid microcarcinomas. J Clin Endocrinol Metab 2010;95(11):4882-8.

30) Grogan RH, Kaplan SP, Cao H, Weiss RE, Degroot LJ, Simon CA, et al. A study of recurrence and death from papillary thyroid cancer with 27 years of median follow-up. Surgery. 2013;154(6):1436-46; discussion 1446-7.

31) Kim SK, Park I, Woo JW, Lee JH, Choe JH, Kim JH, et al. Total thyroidectomy versus lobectomy in conventional papillary thyroid microcarcinoma: Analysis of 8,676 patients at a single institution. Surgery 2017;161(2):485-92.

32) Ahn D, Sohn JH, Kim H, Jeong JY, Jung H. Clinical impact of occult multifocal disease identified after hemithyroidectomy in patients 
with papillary thyroid microcarcinoma. Korean J OtorhinolaryngolHead Neck Surg 2014;57(3):166-71.

33) Khan M, Syed AA, Khan AI, Hussain SR, Urooj N. Association of tumor size and focality with recurrence/persistence in papillary thyroid cancer patients treated with total thyroidectomy along with radioactive-iodine ablation and TSH suppression. Updates Surg
2018;70(1):121-7.

34) Genpeng L, Jianyong L, Jiaying Y, Ke J, Zhihui L, Rixiang G, et al. Independent predictors and lymph node metastasis characteristics of multifocal papillary thyroid cancer. Medicine (Baltimore) 2018; 97(5):e9619. 